\title{
sciendo
}

CIVIL AND ENVIRONMENTAL ENGINEERING REPORTS

E-ISSN 2450-8594

CEER 2021; 31 (1): 0070-0078

DOI: $10.2478 /$ ceer-2021-0005

Original Research Article

\section{TECHNICAL PROBLEMS IN THE RENOVATION OF HISTORIC BRIDGES. CASE STUDY - ROAD BRIDGE IN CIGACICE}

\author{
Magdalena MIELCZAREK ${ }^{1}$, Beata NOWOGOŃSKA ${ }^{1}$ \\ ${ }^{1}$ University of Zielona Góra, Institute of Construction
}

\begin{abstract}
The road bridge in Cigacice is a very good example of and testimony to the level of knowledge and skills in interwar engineering art. The bridge is almost 100 years old, put to use in 1925, and was designed and manufactured by Beuchelt \& Co. in Zielona Góra. The bridge has 10 spans with a parabolic main span, and the supporting structure for the spans is made of steel lattice girders. The object has been strengthened and modernized several times. Currently, renovation works are also being carried out, resulting from identified unfavorable corrosion of the steel elements of the bridge and the concrete bridge slab. The historic steel structure and the bridge supports are being renovated according to the conservation recommendations.
\end{abstract}

Keywords: road bridge, renovation, cultural heritage preservation

\section{INTRODUCTION}

The maintenance and protection of historic bridges requires constant inspection of their technical condition and systematic renovation works $[1-3,6-9,11]$. The technical condition of these engineering structures is related to their age, load intensities changing with time, the aging processes of constituent materials, and

\footnotetext{
${ }^{1}$ Corresponding author: Magdalena Mielczarek, University of Zielona Góra, e-mail: m.mielczarek@ib.uz.zgora.pl
} 
rheological phenomena $[1-3,6-9,11]$. However, apart from technical problems in the production of historic bridge structures, there are problems related to aesthetics and architecture and, therefore, all works should be conducted inconsultation with the conservator of monuments.

The bridge in Cigacice is included in the municipal register of monuments which, pursuant to Art. 39 par. 3. of the Act of June 7, 1994 of Construction Law (Journal of Laws of 2020, item 1333) means that in relation to building structures and areas not entered in the register of monuments, but included in the municipal register of monuments, the permit for building or demolition of the building is issued by the competent authority (in this case, the County Office in Zielona Góra) in agreement with the provincial conservator of monuments. In connection with the above, the so-called conservation recommendations, which contain guidelines for the planned renovation, were issued by the Lubuski Provincial Conservator of Monuments on March 11, 2019.

Despite the partial destruction of the bridge during the war, it has retained its original shape, material, and construction solutions to this day, therefore, the most important thing was to keep the unchanged form, which has been a landmark of the Oder River landscape for many decades. In accordance with the guidelines, during the renovation, it was permissible to replace any secondary elements introduced in the post-war period, such as, e.g. the bridge slab.

\section{HISTORY OF THE BRIGDE}

In 1862, the first permanent bridge was built along the road between Zielona Góra (Grünberg) and Sulechów (Züllichau), in Cigacice (Tschicherzig) on the Oder River. It was a 27-span wooden bridge, supported on wooden piles. Due to the increasing demand for inland navigation, a left-bank (from the Zielona Góra side) double-deck drawbridge was implemented on the Oder Waterway (Oderschiffahrt/Oderwasserstraße) to enable free navigation. The remains of the crossing are the existing abutments - in brick on the right bank and earth on the left (both located below the abutments of the existing crossing).

The wooden crossing lasted until the mid-1920s. Due to the deteriorating technical condition and further-developing inland navigation, the concept of building a new crossing was considered. The initiator of the modern crossing construction was the contemporary starost of Sulechów and Świebodzin, Erich Konrad von Monbrat, who was the local head in 1914-1933. Hence the later name of the Monbrat bridge (Monbartbrücke), from the name of its initiator. 


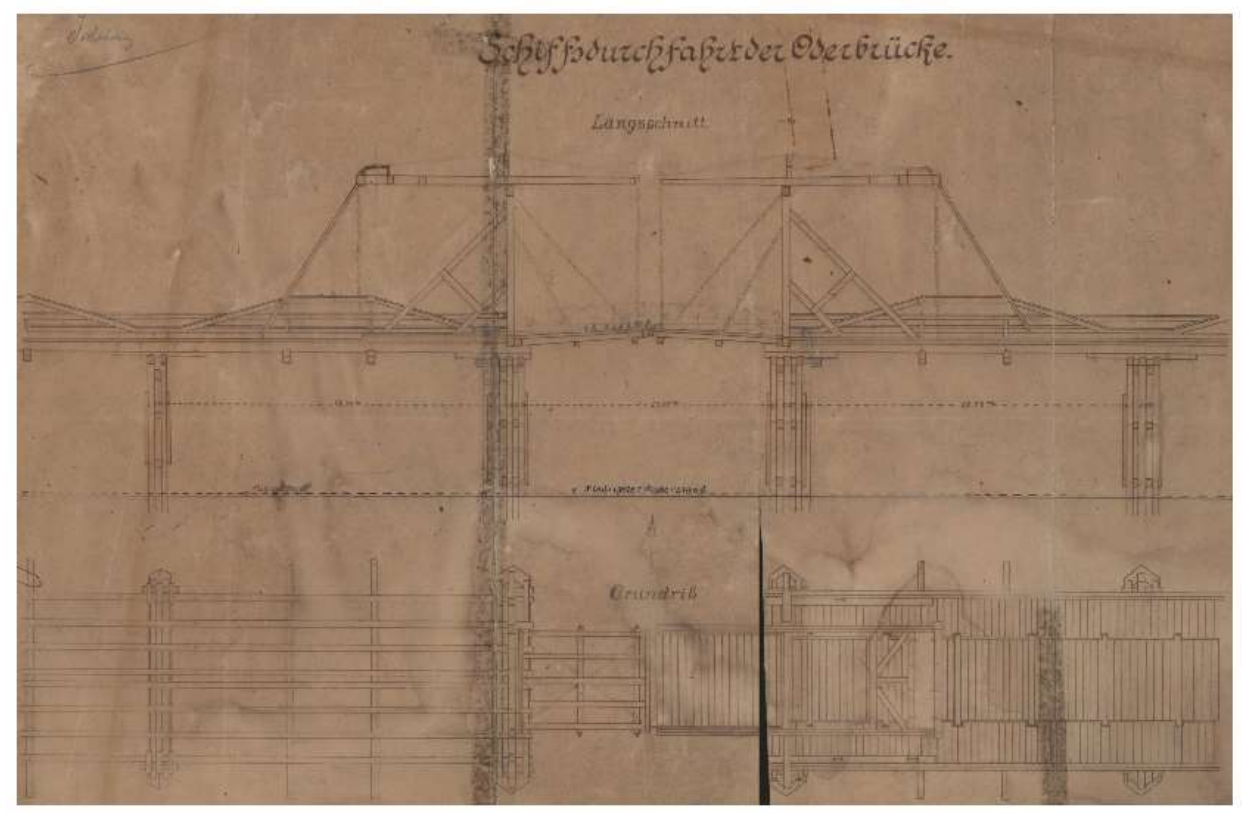

Photo 1. Plan and cross-section of the wooden drawbridge (records of the State Archive in Zielona Góra Sig. 1004)

Both the project and the implementation were entrusted to a domestic company, the world-famous George Beuchelt's Bridge, Steel Structures, and Railway Carriages Construction Factory (Fabrik für Brückenbau-, Waggon-, und Eisenkonstruktion Beuchelt \& Co). From the various concepts submitted, a crossing with massive, vaulted flood spans, with one large navigable steel span was selected. Due to the need to reduce construction costs, the vaults of the flood spans were ultimately omitted. The new bridge was approx. 390 meters long and was a 10-span structure supported on abutments and pillars. During the foundation of the bridge, due to the poor load-bearing capacity of the soil in the Oder riverbed, the foundation of both pillars of the current span was made using the caisson method, a technique that was rarely used at that time. The construction of the bridge was completed in 1925, with the ceremonial opening taking place on April 29 at the bridgehead in Cigacice. In January 1945, the bridge was blown up to prevent any more Soviet tanks from reaching the bank of Zielona Góra. Only the fifth flood span from Zielona Góra was blown up, while the large navigable span survived without major damage. In the 1950s, the damaged span was reconstructed, and the steel structure was provided by the 
"Kościuszko" steelworks in Chorzów. The contemporary crossing faithfully reproduces the form and structure of the Monbart bridge from 1924-1925 [4-5].

\section{TECHNICAL DESCRIPTION OF THE BRIDGE}

The Monbart Bridge is a 384-meter crossing over the Oder River, along the district road no. 1187F, and connects Zielona Góra with Cigacice. It is a 10-span structure with a static diagram of a simply-supported beam (Photo 2).

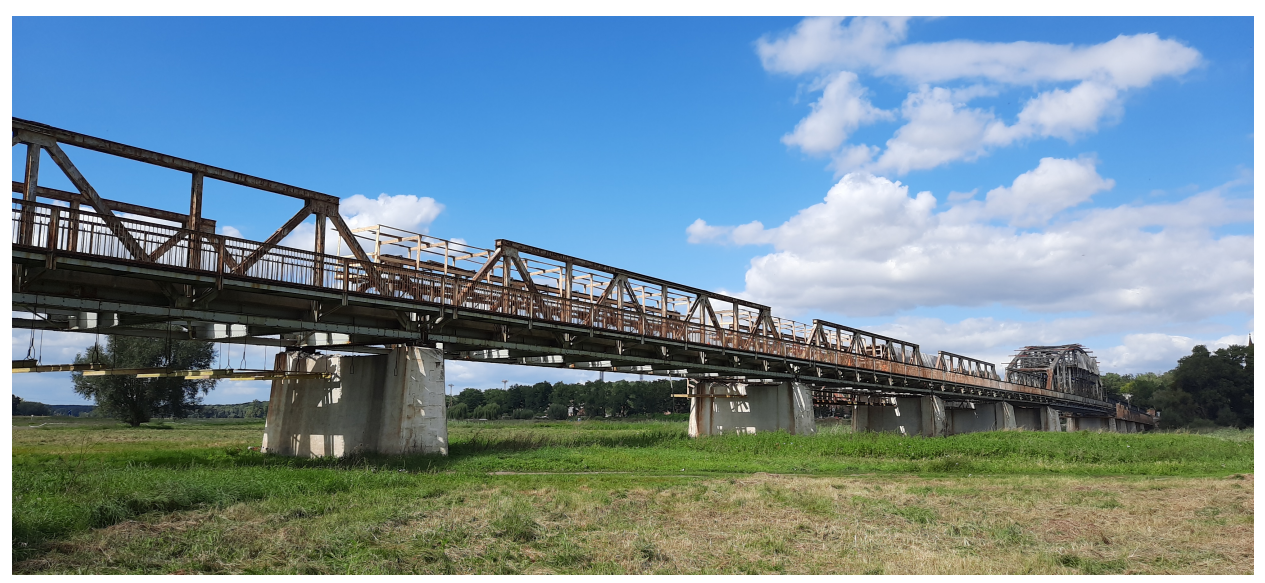

Photo 2. Bridge in Cigacice. South-east view

The first five spans (counting from the Zielona Góra side) are 33.8 meters long and 4.0 meters high, followed by a navigable span with a length of 87 meters and a variable construction height ranging from $6.0 \mathrm{~m}$ to $12.0 \mathrm{~m}$, the remaining four spans are 32.0 meters long and of a constant height of approx. $4.0 \mathrm{~m}$ [10]. The load-bearing structure of all ten spans consists of steel lattice, made of elements with multi-branch sections, connected with rivets. The lattices (differing in line with the breadth and height of individual spans) are connected in the lower chord with crossheads, which are made of several profiles forming an I-beam section. Then, ledgers are supported on them; in the case of the main span, the height of the ledgers is $616 \mathrm{~mm}$, in the remaining spans, the ledgers are made of $320 \mathrm{~mm}$ high sections [10]. On the steel grillage of ledgers and crossheads, a $22 \mathrm{~cm}$ thick reinforced concrete bridge slab was made, with smooth steel reinforcement except for the main span, where ribbed bars were also used. The entire steel structure is rested on two abutments (extreme supports) and nine pillars (middle supports). 


\section{SCOPE OF THE RENOVATION}

The structure of the bridge did not require excessive interference and only a few elements were replaced. Most of the steel load-bearing elements only had surface corrosion (Photo 3). After cleaning, anti-corrosion coatings were applied and, in agreement with the Lubuski Provincial Conservator of Monuments, the entire structure was covered with a dark shade of gray paint.

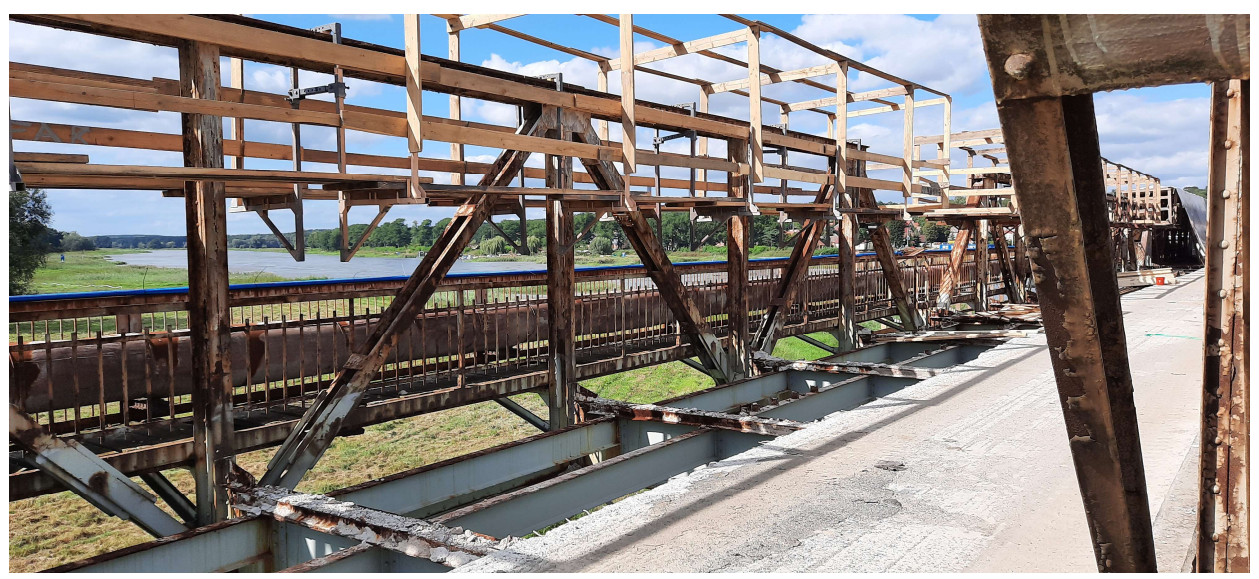

Photo 3. Renovation of the bridge steel structure

Elements damaged by pitting corrosion were reinforced with inserts welded using the MIG/MAG method, and in some places (such as the webs of the extreme crossheads over expansion joints), joining with fitted bolts was additionally applied. Due to the poor technical condition of the reinforced concrete bridge slab, it was planned to be replaced with a slab made of concrete, while maintaining the geometry of the existing dilatational slab (Photo 4). The slab was fully reinforced with ribbed steel bars, and the element was joined to the steel structure with steel ledgers welded to the upper shelf. The crossheads were reinforced, the lower braces were complemented, and their fixing was strengthened. The gusset plates as well as the lower chords within the diagonals were strengthened. The missing lower braces were supplemented, and their fixing was strengthened. The damaged posts were restored to their original geometry, and they were also strengthened in sections. 


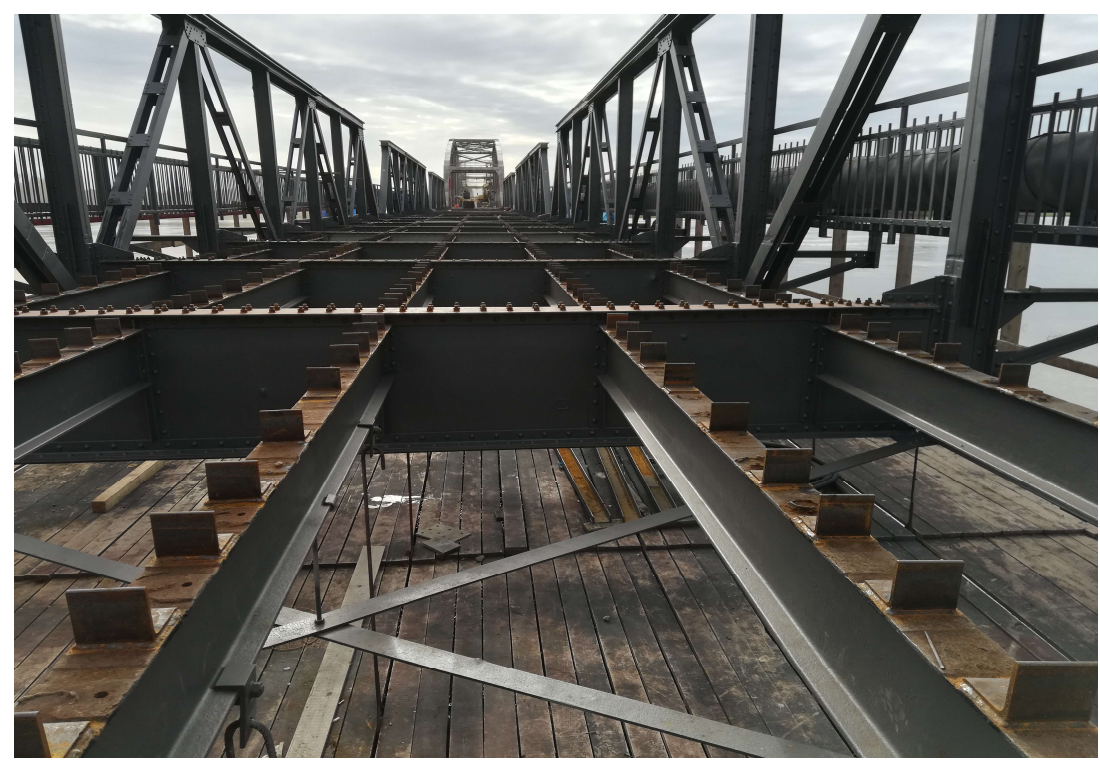

Photo 4. Replacement of the bridge slab

It is also planned to repair the portal gate and protect it with a cover plate to prevent water accumulation inside the bolts. Abutments and pillars only needed to be cleaned, to fill their cavities and apply new coatings. The shafts of the sliding bearings were replaced (the remaining bearing elements were subjected to preservation and securing works), and new planks were made. Additionally, it is planned to replace the surface of the pedestrian route and install concomitant devices (including streetlamps).

\section{PRESERVATION CHALLENGES}

According to Art. 3 par. 1 of the Act of 23 July 2003 on the protection and care of monuments (Journal of Laws of 2020, item 282), a monument - is a real or movable property, parts, or complexes thereof, being the work of a human or related to his activity and being a testimony to a bygone era or events whose preservation is in the public interest due to their historical, artistic, or scientific value.

While in the case of the bridge it is difficult to talk about its artistic value, the scientific value of the crossing is beyond doubt. It stands as testimony to the level of knowledge and skills in the field of interwar bridge engineering. In addition, the object is the result of the craftsmanship achievements of the industrial tycoon of the Bridge Construction Factory, George Beuchelt from Zielona Góra, whose works are known all over the world (including the Berlin 
ZOO train shed, Damascus-Baghdad railway, or the bridge in Tylża). Additionally, we have here historical evidence of warfare, which is still visible today on the steel structure elements (numerous dents or slivers - Photo 5).

The aim of the monument protection office is to preserve the cultural heritage of our country in the best possible form and condition. In the case of buildings so important for the region, cooperation with preservation services is extremely important as such activities increase attention during the performance of works, increase costs, and generate the use of other technologies and methods. Moreover, it is difficult to use the object. In this case, in addition to its aesthetic value, the bridge must meet the standards and conditions enabling contemporary vehicular and pedestrian traffic. In connection with the modernization plans on the Oder River, it was important that the activities related to the preservation protection did not collide with the strategic goals of the Country, aimed at improving the navigability of the Oder Waterway. Despite technological advances and modernization of the country's infrastructure, it is extremely important to care for the cultural heritage and preserve the relics of the past for future generations, so that despite the passage of time, we can still admire the craftsmanship of the past centuries.

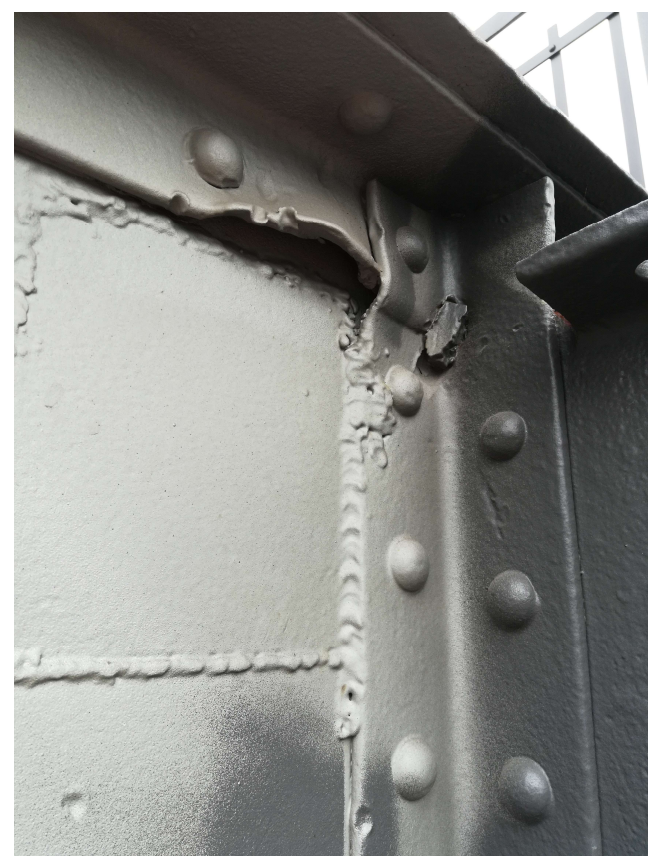

Photo 5. Visible damage resulting from armed conflicts 


\section{SUMMARY}

Monuments are evidence of our history, traditions, and national pride. The bridge in Cigacice is a peculiar example of domestic industry, a work made by the hands of local specialists, known not only in Germany and Poland but also around the world. Thanks to the well-preserved structure of the bridge, there was no need to replace elements, introduce structural changes, or make significant visual changes during the renovation. The structure of the Monbart bridge has undergone only minor modernization over the course of almost 100 years, maintaining its original shape, form, and materials. The restoration of its original colors together with the preservation of the original structural elements with reinforcements and supplements, has allowed the bridge in Cigacice, which was the work of George Beuchelt's Bridge, Steel Structures, and Railway Carriages Construction Factory, to serve future generations in a historic, aesthetic, and safe form, making it a characteristic point of the riverside landscape.

\section{REFERENCES}

1. Czudek, H and Wysokowski, A 2005. Trwałość mostów drogowych. Wydaw. Komunikacji i Łączności, Warszawa.

2. Flaga, K 2011. Diagnostyka, modernizacja i rewitalizacja obiektów mostowych z betonu - część I. Diagnostyka, monitoring i modernizacja eksploatowanych obiektów budowlanych, 56 Konferencja Naukowa Komitetu Inżynierii Lądowej i Wodnej PAN oraz Komitetu Nauki PZITB, Kielce-Krynica 19-24 września 2010, red. nauk. Wiesław Trąmpczyński. Kielce, 2010. - s. 123-156.

3. Flaga, K and Furtak, K 2015. Examples of solutions for steel-concrete composite structures in bridge engineering. Civil and Environmental Engineering Reports. 1 (16), 51-68.

4. Foerster, M 1926. Zum 50 Jährigen Bestehen der Eisenkonstruktionwerkstatten und Brückenbrutanstalt Beuchelt \& Co. in Grünberg, Schlesien Der Bauingenieur z.48 1926.

5. Henke, G 1926. Die neue Starssenbricke über die Oder bei Tschicherzig. Grünberger Hauskalender. Heimatkalender für die Kreise Grunberg und Freystadt auf das Jahr 1926. Grünberg 1926.

6. Madaj, A and Wołowicki, W 2007. Budowa i utrzymanie mostów. Oficyna Wyd. Politechniki Warszawskiej, Warszawa 2007.

7. Radomski, W 2010. What is bridge durability - Official regulations and reality. Bridge Maintenance, Safety, Management and Life-Cycle Optimization - Proceedings of the 5th International Conference on Bridge Maintenance, Safety and Management, 2010, 3498-3503. 
8. Radomski, W and Furtak, K 2006. Obiekty mostowe - naprawy i remonty: podręcznik dla studentów wyższych szkół technicznych. Wydawnictwo Politechniki Krakowskiej, Kraków 2006.

9. Siwowski, T 2008. Propozycja zastosowania zasad zrównoważonego rozwoju w modernizacji mostu. Drogi i mosty 7(3) 55-91.

10. Wroński, E 2018. Ocena stanu technicznego mostu nad rzeką Odrą w ciągu

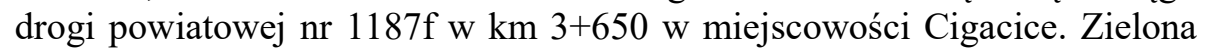
Góra, 2018, https://bip.powiat-zielonogorski.pl/zamowienia publiczne/.

11. Wysokowski, A 2018. Research on changes in properties of steel from the old road bridge. Journal of Constructional Steel Research. Vol. 147, 360366.

Editor received the manuscript: 21.11 .2020 